\title{
PENGGUNAAN MEDIA BAHAN DAUR ULANG UNTUK MENINGKATKAN KREATIVITAS GURU PAUD DI KOTA SURABAYA
}

\author{
Berda Asmara ${ }^{1}$, Pance Mariati ${ }^{2}$ \\ asmaraberda@unusa.ac.id'1 ${ }^{1}$ pance_mariati@unusa.ac.id ${ }^{2}$ \\ Universitas Nahdlatul Ulama Surabaya ${ }^{1,2}$
}

\begin{abstract}
ABSTRAK
Kreativitas melalui media bahan daur ulang merupakan salah satu usaha untuk meningkatkan kreativitas guru PAUD (TK/RA) di Kota Surabaya. Dalam pelaksanaannya adalah pendidik/guru PAUD membuat media pembelajaran yang cocok untuk anak usia dini dengan memanfaatkan media bahan daur ulang, sampai sejauh ini kreativitas yang ditunjukkan guru PAUD (TK/RA) di Kota Surabaya belum semua menunjukkan kreativitasnya hanya $22 \%$ saja yang sudah terlihat kreativitasnya terlebih dengan memanfaatkan bahan daur ulang. Memanfaatkan media bahan daur ulang oleh guru PAUD (TK/RA) masih terasa jauh dari keterjangkauan. Kreativitas merupakan hal yang terpenting khususnya bagi guru / pendidik di PAUD. Kreativitas yang ditujukan untuk mengembangkan anak dalam hal kemampuan berfikir, berapresiasi, bereksplorasi dan berkreasi. Dalam memanfaatkan bahan daur ulang, guru dan anak- anak belajar mengolah perasaan, kepekaan, intuisi dan imajinasinya. Dengan demikian kreativitas di PAUD (TK/RA) menjadi strategis dalam pengembangan kreativitas guru / pendidik dan menyenangkan anak dalam pembelajaran sehari- hari di Lembaga PAUD. Berdasarkan kerangka pemikiran tersebut, sangat diperlukan penelitian yang ditujukan untuk memanfaatkan media bahan daur ulang untuk meningkatkan kreativitas guru / Pendidik di PAUD (TK?RA) yang ada di Surabaya. Penelitian ini merupakan penelitian tindakan kelas (PTK), karena penelitian ini dimaksudkan untuk meningkatkan kreativitas guru PAUD (TK \& RA) di Kota Surabaya, dimana peneliti terlibat langsung dalam proses pemanfaatan media bahan daur ulang yang dijadikan Alat Permainan Edukatif anak usia dini (anak didik). Dalam penelitian ini, peneliti meneliti tentang penggunaan media bahan daur ulang untuk meningkatkan kreativitas Guru PAUD (TK/RA) di Kota Surabaya. Proses pembuatan media bahan daur ulang dirasa berhasil dalam meningkatkan kreativitas Guru PAUD (TK/RA). Pada siklus I ketuntasan meningkatakan kreativitas Guru PAUD (TK/RA) sebesar 65\% meningkat di siklus II menjadi $83 \%$.
\end{abstract}

Kata kunci: media bahan daur ulang,kreativitas, Guru PAUD

\begin{abstract}
Creativity through recycled material media is one of the efforts to increase the creativity of PAUD teachers (TK/RA) in the city of Surabaya. In its implementation, PAUD educators / teachers make learning media suitable for early childhood by utilizing recycled material media, so far the creativity shown by PAUD (TK / RA) teachers in the city of Surabaya has not all shown that creativity is only $22 \%$ that has been seen. creativity especially by utilizing recycled materials. Utilizing recycled material by PAUD (TK / RA) teachers still feels far from being affordable. Creativity is the most important thing especially for teachers / educators in PAUD. Creativity aimed at developing children in terms of ability to think, appreciate, explore and be creative. In utilizing recycled materials, teachers and children learn to process their feelings, sensitivity, intuition and imagination. Thus creativity in PAUD (TK / $R A$ ) becomes strategic in developing the creativity of teachers / educators and pleases children in daily learning at PAUD Institutions. Based on this framework, it is very necessary to conduct research aimed at utilizing recycled material media to increase the creativity of teachers / educators in PAUD (TK? RA) in Surabaya. This research is a classroom action research $(C A R)$, because this research is intended to increase the creativity of early
\end{abstract}




\section{PENGGUNAAN MEDIA BAHAN DAUR ULANG UNTUK MENINGKATKAN KREATIVITAS GURU PAUD DI KOTA SURABAYA}

childhood teachers (TK \& RA) in the city of Surabaya, where researchers are directly involved in the process of utilizing recycled material media which is used as an early childhood educational game (students ) In this study, researchers examined the use of recycled material media to improve the creativity of PAUD Teachers (TK/RA) in the City of Surabaya. The process of making recycled material media is considered successful in enhancing the creativity of PAUD Teachers (TK/RA). In the first cycle completeness increased the creativity of early childhood teachers (TK/RA) by $65 \%$ increased in the second cycle to $83 \%$

Key words: media recycling materials, creativity, Early Childhood Education Teachers. 


\section{PENDAHULUAN}

Kata media berasal dari bahasa latin medius yang secara harfiah berarti "tengah", "perantara" atau "pengantar". Media adalah perantara atau pengantar pesan dari pengirim kepada penerima pesan. Arsyad (2013:3) mengatakan bahwa media apabila dipahami secara garis besar adalah manusia, materi, atau kejadian yang membangun kondisi yang membuat sanak didik mampu memperoleh pengetahuan.

$\begin{array}{lcr} & \text { Oemar } & \text { Hamalik } \\ \text { berpendapat } & \text { bahwa } & \text { yang } \\ \text { dimaksud } & \text { dengan } & \text { media } \\ \text { pembelajaran } & \text { merupakan } & \text { alat, } \\ \text { tehnik, dan } & \text { metode } & \text { yang } \\ \text { digunakan } & \text { dalam bilangan } \\ \text { lebih } & \text { mengefektifkan } \\ \text { komunikasi dan interaksi antara } \\ \text { pendidikan } & \text { dan siswa dalam } \\ \text { proses pendidikan ran } & \text { dan } \\ \text { pengajaran } & \text { disekolah } \\ \text { (2008:123) Menurut Heinich, }\end{array}$

Molenda dan Russel (dalam Depdiknas, 2008) diungkapkan bahwa media "is a channel communication.

Derived from the latin word for "between", the term refers "to anything that carries information between a

$\begin{array}{lr}\text { source and a receiver". } \\ \text { Pembelajaran } & \text { dengan } \\ \text { menggunakan media akan } \\ \text { memberikan gairah dalam } \\ \text { belajar, anak berkembang } \\ \text { menurut minat dan }\end{array}$

kecepatannya, interaksi langsung dengan lingkunagan, memberikan rangsangan dan pengalaman yang menimbulkan persepsi akan sebuah konsep yang sama (Trianto, 2009:235).

Dalam era perkembangan Ipteks yang begitu pesat dewasa ini profesionalisme pendidik tidak cukup hanya dengan kemampuan membelajarkan anak, tetapi juga harus mampu mengelola informasi dan lingkungan untuk memfasilitasi kegiatan siswa. Berbagai pendidikan dan sarana pendidikan yang modern turut mendukung optimalisasi proses pembelajaran perkembangan tekhnologi khususnya tekhnologi informasi dan komunikasi banyak menawarkan berbagai kemudahan dalam pembelajaran.

Pembelajaran dengan menggunakan media akan memberikan gairah dalam belajar, anak berkembang menurut minat dan kecepatannya, interaksi langsung dengan lingkunagan, memberikan rangsangan dan pengalaman yang menimbulkan persepsi akan sebuah konsep yang sama (Trianto, 2009:235).

Alasan peneliti menggunakan media bahan daur ulang yang masih bisa terpakai untuk dijadikan Alat Permainan Edukatif untuk anak usia dini, sebagai strategi untuk 
meningkatkan kreativitas terhadap guru PAUD (TK/RA) di Kota Surabaya, yang harus dilakukan adalah membuat media pembelajaran yang cocok untuk anak usia dini melalui media bahan daur ulang. Contoh bahan daur ulang yang bisa dimanfaatkan menjadi Alat Permainan Edukatif untuk anak usia dini, seperti botol plastik, gelas plastik, kardus bekas susu formula, kardus bekas botol minuman, kulit jagung, kain perca, dan lain sebagainya.

Kreativitas melalui media bahan daur ulang merupakan salah satu usaha untuk meningkatkan kreativitas guru PAUD (TK/RA) di Kota Surabaya beserta dengan anak didiknya. Dalam pelaksanaannya adalah pendidik PAUD (TK/RA) membuat media pembelajaran yang cocok dengan anak usia dini dengan memanfaatkan media bahan daur ulang, sampai sejauh ini kreativitas yang ditunjukkan guru PAUD (TK/RA) di Kota Surabaya belum semua menunjukkan kreativitasnya hanya $18 \%$ saja yang sudah terlihat kreativitasnya terlebih dengan memanfaatkan bahan daur ulang (bahan bekas). Memanfaatkan bahan daur ulang oleh guru PAUD (TK/RA) masih terasa jauh dari keterjangkauan.

\section{Rumusan Masalah}

Memperhatikan latar belakang tersebut diatas maka penelitian ini dapat dirumuskan suatu permasalah sebagai berikut: "Apakah Penggunaan Media Bahan Daur Ulang dapat Meningkatkan Kreativitas Guru PAUD di Kota Surabaya"

\section{Tujuan Penelitian}

Tujuan dari penelitian ini adalah sebagai berikut: "Untuk Mengetahui Apakah Penggunaan Media Bahan Daur

Ulang dapat Meningkatkan Kreativitas Guru PAUD di Kota Surabaya"

\section{Manfaat Penelitian}

1. Bagi Guru

-. Memberikan informasi tentang manfaat media bahan daur ulang untuk meningkatkan Kreativitas Guru PAUD.

- Sebagai sarana dalam menciptakan media pembelajaran dengan memanfaatkan bahan daur ulang.

- Sebagai sarana dalam menumbuhkan motivasi dalam meningkatkan kreativitas Guru PAUD.

2. Bagi Anak Didik

Dapat meningkatkan kreativitas Guru PAUD dalam memanfaatkan media bahan 
daur ulang.

3. Bagi Lembaga PAUDHasil penelitian ini dapat dijadikan sebagai modul dalam memanfaatkan media bahan daur ulang dijadikan media pembelajaran berupa Alat Permainan Edukatif.

Definisi Operasional Variabel, Asumsi, dan Keterbatasan Definisi Operasional Variabel

Yang dimaksud disini adalah definisi operasional variabel. Dalam penelitian ini ada dua variabel yaitu variabel bebas (Penggunaan Media Bahan Daur Ulang) dan variabel terikat (Peningkatan Kreativitas Guru PAUD).

Variabel Bebas (Penggunaan Media Bahan Daur Ulang) Menurut Heinich, Molenda dan Russel (dalam Depdiknas, 2008) diungkapkan bahwa media "is a channel communication. Derived from the latin word for "between", the term refers "to anything that carries information between a source and a receiver".

Variabel Terikat (Peningkatan Kreativitas Guru PAUD)

James J. Gallagher (1985) mengatakan bahwa "Creativity is a mental process by which an individual creates new ideas or products, or recombines existing ideas and product, in fashion that is novel to him or her" (kreativitas merupakan suatu proses mental yang dilakukan individu berupa gagasan ataupun produk baru, atau mengombinasikan antara keduanya yang pada akhirnya akan melekat pada dirinya).

\section{Asumsi}

Asumsi adalah suatu anggapan dasar yang diyakini kebenarannya oleh peneliti dan dijadikan dasar untuk langkah penelitian.

Dengan judul penelitian "Penggunaan Media Bahan Daur Ulang untuk Meningkatkan Kreativitas Guru PAUD di Kota Surabaya". Maka dapat diasumsikan:

a. Dengan menggunakan media bahan daur ulang akan meningkatkan kreativitas Guru PAUD, yang aktif dalam membuat media pembelajaran berupa Alat Permainan Edukatif yang cocok untuk Anak Usia Dini.

b. Dalam penggunaan media bahan daur ulang akan membawa harapan dan memberi kegembiraan pada Guru PAUD.

\section{Keterbatasan}

Dalam pelaksanaan
penelitian ini, peneliti
mempunyai
sebagai berikut:

a. Penelitian ini hanya terbatas pada penggunaan media daur 
ulang dengan meningkatkan kreativitas Guru PAUD (TK/RA).

b. Penelitian dengan menggunakan observasi.

c. Penelitian ini hanya berlaku pada Guru PAUD (TK/RA) di Kota Surabaya.

d. Media yang digunakan terbatas pada pemanfaatan media bahan daur ulang.

\section{METODE PENELITIAN}

Langkah-langkah setiap siklus dalam penelitian ini, dapat dibagi menjadi empat tahap, yaitu :

\section{Siklus I}

\section{Rancangan/rencana awal}

Implementasi siklus pada rancangan/rencana awal ini adalah meningkatkan kreativitas guru PAUD (TK/RA), dalam memanfaatkan media bahan daur ulang serta hasil belajar anak didik dalam menggunakan Alat

Permainan Edukatif dari bahan daur ulang yang di sesuaikan dengan Rencana Pelaksanaan Pembelajaran Harian (RPPH) yang dibuat.

\section{Pelaksanaan}

Sebagaimana dikemukakan (dalam Suharjono, 2008: 39). Pada tahap Implementasi dilaksanakan proses pembuatan Alat Permainan Edukatif dari media bahan daur ulang, alat dan bahan yang akan digunakan, langkah-langkah pembuatannya, serta cara mengaplikasikan pada anak didik.

\section{Pengamatan}

Data yang dikumpulkan selama tindakan berlangsung kemudian dianalisis. Berdasarkan hasil analisis ini peneliti melakukan pengamatan, yaitu pengamatan dilakukan bersamaan dengan pelaksanaan pembelajaran atau tindakan. Tujuan diadakan pengamatan adalah untuk memperoleh gambaran secara cermat tentang tindakan yang sedang dilakukan dan kemudian

didokumentasikan. Hasil pengamatan akan terlihat tingkat keberhasilan dan kegagalan yang dicapai dalam tindakan perbaikan.

\section{Refleksi}

Hasil refleksi ini merupakan masukan peneliti dalam merencanakan dan melaksanakan tindakan perbaikan berikutnya. Refleksi dapat dilakukan peneliti bersama teman sejawat, bertujuan untuk mengkaji dan menganalisis pelaksanaan tindakan pada siklus 1 dengan jalan mengidentifikasi baik kemajuan-kemajuan yang telah diperoleh maupun kekurangan-kekurangan atau 


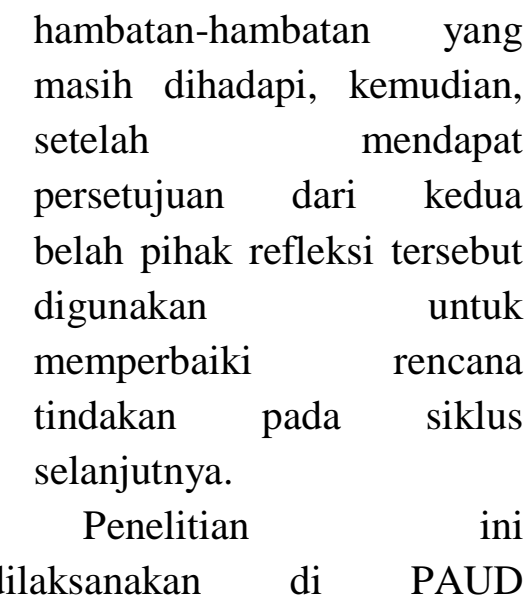

(TK/RA) Kota Surabaya, ada 10 Lembaga PAUD (TK/RA) yang tersebar di 10 (sepuluh) Kecamatan dan 10 (Sepuluh) Kelurahan yang ada di Wilayah Kota Surabaya. Setiap PAUD (TK/RA) ada 1-2 Bunda PPT yang menjadi subjek penelitian.

Lokasi penelitian berada di Wilayah Kota Surabaya; Surabaya bagian barat, surabaya bagian utara, surabaya bagian selatan, surabaya timur dan surabaya pusat.

Instrumen pengumpulan data yang digunakan dalam penelitian ini menggunakan pedoman observasi dan dokumentasi. Pedoman ini untuk mengetahui kebutuhan pengguna. observasi dilakukan di Beberapa Lembaga PAUD (TK/RA) yang ada di Surabaya. Sedangkan, dokumentasi dilakukan untuk mendapatkan data pendukung, misalnya data identitas guru PAUD yang mengajar di TK maupun RA yang ada di beberapa kecamatan di Surabaya dan foto untuk mengetahui secara langsung pembuatan alat permainan edukatif dari media bahan daur ulang.

Instrumen yang digunakan dalam penelitian ini adalah berupa Format Lembar Kreativitas Guru PAUD (TK/RA)

di Kota Surabaya dengan memanfaatkan media bahan daur ulang dijadikan sebagai media pembelajaran berupa Alat Permainan Edukatif yang cocok untuk anak didik (anak usia dini).

Analisa data ini merupakan lanjutan dari kegiatan pengumpulan data. Untuk itu, seorang peneliti perlu memahami teknik analisis data yang tepat agar manfaat penelitiannya memiliki nilai yang tinggi.

Data yang diperoleh dalam penelitian ini adalah data peningkatan kreativitas guru PAUD (TK/RA) di Kota Surabaya dengan memanfaatkan media bahan daur ulang dapat dijadikan media pembelajaran yang cocok untuk anak usia dini. Data yang sudah terkumpul kemudian dianalisis.

Data yang diperoleh di analisis menggunakan patokan standar keberhasilan. Guru dikatakan berhasil apabila telah mencapai standar prosentase $\geq$ $75 \%$. 


\section{HASIL PENELITIAN DAN PEMBAHASAN}

Penelitian ini merupakan penelitian tindakan kelas (PTK), karena penelitian ini dimaksudkan untuk meningkatkan kreativitas guru PAUD (TK/RA) di Kota Surabaya, dimana peneliti terlibat langsung dalam proses pemanfaatan media bahan daur ulang yang dijadikan media pembelajaran untuk anak usia dini (anak didik). Dalam penelitian ini, peneliti meneliti tentang penggunaan media bahan daur ulang untuk meningkatkan kreativitas Guru PAUD (TK/RA) di Kota Surabaya. Dari penelitian ini dapat dideskripsikan secara rinci hasil penelitian dan pembahasan sebagai berikut:

\section{Hasil Penelitian}

1. Pra Siklus

Kegiatan pra siklus dilakukan untuk mengetahui sejauh mana peningkatan kreativitas Guru PAUD (TK/RA) dalam memanfaatkan media bahan daur ulang yang dijadikan Alat Permainan Edukatif sebagai media pembelajaran yang cocok untuk anak usia dini (anak didik). Hasil dari pra siklus yang dilakukan oleh peneliti menunjukkan bahwa permasalahan yang ditemukan peneliti pada
Guru PAUD (TK/RA) di Kota Surabaya yang pertama adalah tidak adanya Alat Permainan Edukatif yang menarik untuk anak didiknya, kemudian permasalahan yang kedua adalah keterbatasan sarana prasarana di Lembaga PAUD (TK/RA) yang saya teliti di Kota Surabaya, kondisi seperti inilah yang menjadikan kurangnya kreativitas pada Guru PAUD (TK/RA) di PPT Kota Surabaya

Melihat kondisi tersebut, maka dilakukan penelitian tindakan kelas dengan penggunaan media bahan daur ulang untuk meningkatakan kreativitas Guru PAUD (TK/RA) di Kota Surabaya.

2. Pelaksanaan Tindakan Siklus I Penelitian tindakan kelas ini dilakukan untuk meningkatkan kreativitas Guru PAUD (TK/RA) di Kota Surabaya melalui pemanfaatan media bahan daur ulang yang dijadikan Alat Permainan Edukatif sebagai media pembelajaran yang cocok untuk anak usia dini. Pada proses kali ini yang dilakukan terlebih dahulu adalah memilih dan menentukan jenis bahan daur ulang apa yang akan digunakan dalam pembuatan Alat Permainan Edukatif yang cocok untuk anak usia dini.

\section{a. Perencanaan}


1). Siklus I Pertemuan Pertama

a). Menyusun Rencana Pelaksanaan Pembelajaran Harian

b). Menyusun jenis Alat Permainan Eedukatif yang akan dibuat dari bahan daur ulang c). Menyusun jenis bahan daur ulang yang akan di kelola.

2) Siklus I Pertemuan Kedua Pada tahap ini, peneliti memberikan pemecahan terhadap kendala-kendala yang ditemukan peneliti pada waktu proses pembuatan media bahan daur ulang pada pertemuan pertama. Dari hasil pengamatan yang ada pada pertemuan pertamam selanjutnya peneliti melakukan perencanaan tindakan selanjutnya dengan langkah-langkah sebagai berikut:

a). Menyusun Rencana Pelaksanaan Pembelajaran Harian (RPPH)

b). Menentukan jenis APE yang akan dibuat dari bahan daur ulang yang sesuai dengan tema yang ada di RPPH. c). Menentukan jenis bahan daur ulang yang akan di kelola terutama yang dikenal anak didik.

\section{b. Pelaksanaan}

pelaksanaan tindakan siklus I ini mengacu pada langkahlangkah pembelajaran yang tertulis dalam RPPH dan akan dilaksanakan oleh Guru PAUD (TK/RA) untuk meningkatkan kreativitas dalam memanfaatkan bahan daur ulang yang akan dijadikan media pembelajaran berupa Alat Permainan Edukatif.

Adapun pelaksanaan kedua pertemuan adalah sebagai berikut:

1). Pertemuan Pertama

a. Guru menanyakan tema

b. Guru memberikan materi sesuai dengan tema yang sudah dibuat dalam RPPH

c. Guru mengajak anak didik berdiskusi dan tanya jawab tentang tema yang sudah diberikan

2). Pertemuan Kedua

a. Setelah anak-anak mengetahui tema yang sudah dijelaskan guru, guru akan mengenalkan Alat Permainan Edukatif yang sudah dibuat dari bahan daur ulang

b. Guru memberi kesempatan kepada anak untuk menggunakan APE tersebut yang sudah disesuaikan dengan tema dan RPPH. 


\section{Hasil Pengamatan atau}

Observasi

Hasil

Peningkatan

Kreativitas Guru PAUD (TK/RA).

Proses pembuatan media pembelajaran dari bahan daur ulang diawali dengan guru mengajak anak untuk berdiskusi tentang APE yang disukai oleh anak usia dini (anak didik) sesuai dengan tema dan RPPH. Berdasarkan hasil observasi ini dan penilaian yang dilakukan peneliti terhadapa kreativitas Guru PAUD (TK/RA) di Kota Surabaya pada siklus I.

Dari hasil analisis pada tahap siklus I, diperoleh data yang menunjukkan bahwa kreativitas Guru PAUD (TK/RA) dalam memanfaatkan media bahan daur ulang yang dapat dijadikan media pembelajaran berupa Alat Permainan Edukatif yang cocok untuk anak usia dini di Kota Surabaya mencapai $65 \%$. Namun hasil ini belum mencapai standar persentasi minimal yaitu $\geq 75 \%$ dari jumlah Guru PAUD (TK/RA) di Kota Surabaya.

- Refleksi

$\begin{array}{lrr}\text { Pada siklus I telah } \\ \text { menunjukkan adanya } & \text { suatu } \\ \text { peningkatan dibandingkan pada } \\ \text { waktu pra siklus. Namun hasil } \\ \text { pada siklus I masih belum } \\ \text { memuaskan dan belum sesuai }\end{array}$

dengan harapan peneliti. Hal ini karena standar persentase yang masih $\geq 75 \%$ yaitu persentase ketuntasan yang diraih oleh Guru PAUD (TK/RA) adalah sebesar $65 \%$.

\section{3). Pelaksanaan Tindakan}

Siklus II

Pelaksanaan tindakan siklus II ini dimaksudkan utnuk mengatasi kendala-kendala yang muncul pada siklus I dan memperbaiki masalah yang terdapat dalam siklus I dapat teratasi.

Adapun pelaksanaan siklus II dapat diuraikan sebagai berikut:

a. Perencanaan

1). Siklus I Pertemuan Pertama

a. Menyusun Rencana

Pelaksanaan Pembelajaran Harian

b. Menetapkan jenis Alat Permainan Eduktif yang sudah dibuat dari bahan daur ulang sesuai dengan tema.

c. Menetapkan jenis bahan daur ulang yang akan di kelola.

2) Siklus II Pertemuan Kedua

Pada tahap ini, peneliti memberikan pemecahan terhadap kendala-kendala yang ditemukan peneliti pada waktu proses pembuatan media bahan daur ulang pada pertemuan pertama. Dari hasil pengamatan yang ada pada pertemuan pertama selanjutnya peneliti melakukan perencanaan 
tindakan selanjutnya dengan langkah-langkah sebagai berikut:
a. Menyusun
Rencana
Pelaksanaan Pembelajaran Harian (RPPH).
b. Mendemonstrasikan Alat Permianan Edukatif yang sudah dibuat dari bahan daur ulang

\section{b. Pelaksanaan \\ Pelaksanaan tindakan} siklus II ini mengacu pada langkah-langkah pembelajaran yang tertulis dalam RPPH dan akan dilaksanakan oleh Guru PAUD (TK/RA) untuk meningkatkan kreativitas dalam memanfaatkan media bahan daur ulang yang dijadikan media pembelajaran yaitu Alat Permainan Edukatif.

$$
\text { Adapun pelaksanaan }
$$

kedua pertemuan adalah sebagai berikut:

1). Pertemuan Pertama
a. Guru menanyakan tema hari ini
b. Guru memberikan materi sesuai dengan tema yang sudah dibuat dalam RPPH
c. Guru mengajak anak berdiskusi dan tanya jawab tentang tema yang sudah diberikan

2). Pertemuan Kedua
a. Setelah anak-anak mengetahui tema yang sudah dijelaskan guru, guru akan mengenalkan media pembelajaran Alat Permainan Edukatif yang sudah dibuat dari bahan

daur ulang

b. Guru memberi kesempatan kepada anak untuk menggunakan APE dari media bahan daur ulang tersebut yang sesuai dengan tema dan berwarma-warni yang menarik untuk anak didik dan sesuai dengan RPPH.

\section{c.Hasil Pengamatan atau Observasi}

Hasil Peningkatan

Kreativitas Guru PAUD

(TK/RA)

Proses pembuatan media pembelajaran dari bahan daur ulang diawali dengan guru mengajak anak untuk berdiskusi tentang APE yang disudah dibuat oleh Guru PAUD (TK/RA) dengan sedemikian menarik, dengan warna-warni dan cocok di aplikasikan pada anak usia dini (anak didik) sesuai dengan tema dan RPPH. Berdasarkan hasil observasi ini dan penilaian yang dilakukan peneliti terhadap kreativitas Guru PAUD (TK/RA) di Kota Surabaya pada siklus II.

Dari hasil analisis pada tahap siklus I, diperoleh data yang menunjukkan bahwa kreativitas Guru PAUD (TK/RA) dalam memanfaatkan bahan daur ulang dijadikan media pembelajaran berupa Alat 
Permainan Edukatif yang cocok untuk anak usia dini di TK maupun RA Kota Surabaya mencapai $83 \%$ dari semula yang hanya $65 \%$ dari hasil siklus I. Hasil tersebut sudah mencapai standar persentase $\geq$ $75 \%$ dari jumlah Guru PAUD (TK/RA) di Kota Surabaya.

\section{d. Refleksi}

$$
\text { berdasarkan }
$$

observasi terhadap peningkatan kreativitas Guru PAUD (TK/RA) selama pelaksanaan pada siklus II menunjukkan bahwa adanya suatu peningkatan. Hal ini dapat dilihat dari hasil persentase ketuntasan pada siklus II mencapai $82 \%$. Dari uraian tersebut, maka proses peingkatan kreativitas Guru PAUD dalam siklus II termasuk dalam kriteria sangat baik.

Hal ini menunjukkan bahwa pelaksanaan siklus II sudah bisa dikatakan berhasil dan dirasa cukup mewakili dari tujuan yang telah direncanakan yaitu untuk mengetahui apakah pemanfaatan media bahan daur ulang dapat meningkatkan kreativitas Guru PAUD (TK/RA) di Kota Surabaya.

Dengan demikian penelitian tindakan kelas dalam penelitian ini dapat dilakukan sampai pada siklusII

\section{PEMBAHASAN}

Penelitian tindakan kelas ini dilakukakn secara bertahap, dimulai dari pra siklus, kemudian siklus I dan dilanjutkan siklus II, dimana perencanaan tindakan pada siklus I bersumber dari masalah-maslaah yang menghambat kreativitas Guru PAUD (TK/RA) sehingga kreativitas Bunda/Guru PAUD pada awal pelaksanaan relatif rendah. Dengan pemanfaatan media bahan daur ulang pada penelitian tindakan kelas ini, diharapkan Guru PAUD (TK/RA) dapat meningkatkan kreativitasnya dalam membuat media pembelajaran berupa Alat Permainan Edukatif yang cocok untuk anak usia dini (anak didik).

Peningkatan kreativitas Guru PAUD (TK/RA) ini terjadi karena adana revisi dan pembaharuan, misalnya Alat Permainan Edukatif yang dibuat dari bahan daur ulang sangat menarik, warnanya sangat bervariasi sehingga dalam mengaplikasikannya mudah dan aman untuk anak usia dini. Dengan demikian penggunaan media bahan daur ulang dapat meningkatkan kreativitas Guru PAUD (TK/RA), memperbanyak APE dari bahan daur ulang sehingga anak didik tidak bosan dengan media pembelajaran yang diberikan oleh Guru PAUD (TK/RA) dan sebagai acuan untuk Guru PAUD (TK/RA) 
yang lain dapat termotivasi untuk meningkatkan kreativitasnya.

Proses pembuatan media pembelajaran dari bahan daur ulang dirasa berhasil dalam meningkatkan kreativitas Guru PAUD (TK/RA). Pada siklus I ketuntasan meningkatakan kreativitas Guru PAUD (TK/RA) sebesar $65 \%$ meningkat di siklus II menjadi $82 \%$.

Dengan demikian penelitian ini membuktikan teori kognitif rasional (dalam Masnipal 2013:222) memandang kreativitas sebagai proses fungsi kemampuan kognitif, terutama kemampuan berpikir kreatif dalam memecahkan masalah. (Torrace 1980, 1963; Taylor 1974; Parnes ; 1967). Hal ini berarti menunjukkan bahwa dengan penggunaan media bahan daur ulang untuk meningkatkan kreativitas Guru PAUD (TK/RA) di Kota Surabaya.

\section{SIMPULAN}

Berdasarkan hasil penelitian dan pembahasan pada bab sebelumnya yang menunjukkan adanya peningkatan kreativitas Guru PAUD (TK/RA) mengalami peningkatan setiap siklusnya.

Hal ini dapat dipaparkan oleh peneliti yakni melalui media bahan daur ulang dapat meningkatkan kreativitas Guru
PAUD (TK/RA) di Kota Surabaya. Hal ini dapat ditunjukkan dengan pencapaian pada siklus I sebesar $65 \%$ dan meningkat pada siklus II sebesari $82 \%$.

Dari uraian tersebut diatas menunjukkan bahwa hasil peningkatan kreativitas Guru PAUD (TK/RA) sudah mencapai standar persentase $\geq 75 \%$ dari keseluruhan Guru PAUD (TK/RA) di Kota Surabaya. Sehingga dapat ditarik

suatu kesimpulan bahwa melalui penggunaan media bahan daur ulang dapat meningkatkan kreativitas Guru PAUD (TK/RA) di Kota Surabaya.

\section{SARAN}

\section{1). Bagi Lembaga PAUD}

a. Untuk Lembaga pendidikan anak usia dini (PAUD) dapat menggunakan media bahan daur ulang yang berupa APE untuk meningkatakn kreativitas Guru PAUD di Kota Surabaya.Pendidik/Guru PAUD dapat meningkatkan kreativitasnya dalam memanfaatkan media bahan daur ulang dijadikan media pembelajaran berupa APE yang sangat menarik dan cocok digunakan pada anak usia dini dalam kesehariannya.

\section{Bagi Peneliti Lain}

a. Penelitian ini dapat dijadikan 
sebagai acuan bagi peneliti berikutnya khususnya pada peningkatan kreativitas Guru PAUD di Kota Surabaya dalam memanfaatkan media pembelajaran dari bahan daur ulang yang menarik.

b. Fokus pada subyek penelitian Pendidik/Guru PAUD (TK/RA) di Kota Surabaya diharapkan dapat diperluas dengan subyek yang lebih besar lagi dan latar belakang serta permasalahan yang berbeda.

\section{DAFTAR PUSTAKA}

Admin. 2012. Pengertian Media Pembelajaran (Online), (html, diakses tanggal 23 April 2015). Arikunto, dkk. 2010, Penelitian Tindakan Kelas, Jakarta: PT Bumi Aksara

Arikunto, Suharsimi. 2006. Prosedur Penelitian. Jakarta:Rineka Cipta Arsyad, Azhar. 2009. Media Pembelajaran. Jakarta: Rajawali Pers. Asyhar, Rayandra, 2011. Kreatif Mengembangkan Media Pembelajaran. Jakarta: Gaung Persada Aqib, Zainal. 2009. Belajar dan Pembelajaran di Taman Kanak-Kanak. Bandung: Yrama Widya. Departemen Pendidikan

Nasional, 2007. Pedoman Pembelajaran Kognitif di
Taman Kanak-Kanak. Jakarta: Dirjen Manajemen Dikdasmen, Direktoral Pembinaan TK dan SD.

Depdiknas. 2008.

Pengembangan Model Pembelajaran di Taman Kanak-Kanak. Direktorat Pembinaan Taman KanakKanak dan Sekolah Dasar. Lowenfeld, V. dan Brittain, W.L. 1982.Creative and Mental Growth. New York: Macmillan Publishing Co. Masnipal, 2013. Siap Menjadi Guru dan Pengelola PAUD Profesional. Jakarta: PT. Gramedia

Sudono, Anggani. 2000. Sumber Belajar dan Alat Permainan untuk Pendidikan Anak Usia Dini. Jakarta: PT Grasindo. Sudjana, Nana dan Rivai, Ahmad. 2010.

Media

Pengajaran. Bandung:

Sinar Beru Algesindo.

Suharjono. 2008. Penelitian Tindakan Kelas dan Karya Ilmiah. Jakarta: Pustaka Prestasi

Suharsimi, Arikunto. 2010. Prosedur Penelitian - Suatu Pendekatan Praktik. Jakarta: Rineka Cipta.

Sujiono, Nurani, Yuliani \& Sujiono, Bambang. 2010. Bermain Kreatif Berbaris Kecerdasan Jamak. Jakarta: PT. Indeks.

Susanto, Ahmad. 2011. 


\section{Berda Asmara $^{1}$, Pance Mariati ${ }^{2}$}

Pekembangan Anak Usia

Dini. Jakarta: Kencana

Prenada Group. Tim

Penyusun PLPG. 2011,

Modul Guru Taman kanak-

kanak, Surabaya: Unesa

Wardhani, I.G.A.k. 2007.

Penelitian Tindakan Kelas.

Jakarta: UT

Yulianty, Rani. 2011. Permainan

yang

Menignkatkan

Kecerdasan Anak. Jakarta

askar Aksara. 